\title{
Experimental studies on changes in mechanical properties of polymer composites under impact of thermal load determined based on compression testing
}

\author{
Agata Walczak ${ }^{1, *}$, Ireneusz Naworol $^{1}$, Daniel Pieniak ${ }^{2}$, Kamil Pasierbiewicz ${ }^{2}$, Grzegorz \\ Dzień $^{1}$ \\ ${ }^{1}$ The Main School of Fire Service, Faculty of Fire Safety Engineering, 52/54 Slowackiego St., \\ 01-629 Warsaw, Poland \\ ${ }^{2}$ University of Economics and Innovation in Lublin, 4 Projektowa St., 20-209 Lublin, Poland
}

\begin{abstract}
The objective of the study was to carry out an analysis of changes in mechanical properties of polymer composites in conditions of thermal load. Such an analysis may allow an initial verification of possibilities of deploying new composites in production of fire helmet shells. The reference material chosen for testing was the Ultramid composite, which is currently used for the production of fire helmet shells. In addition three different materials were selected that contained reinforcement by glass fibres bearing the trade name of Tarnamid, which are not used in manufacturing of shells. Testing was conducted in conditions of quasi-static load, during which compressive tests were performed. Mechanical loads were applied at different levels of thermal exposure, which was to simulate presence in fire conditions. Results of tests indicated that the Tarnamid composites are characterised by better compressive strength and rigidity determined on the basis of the Young module value than Ultramid PA66 GF25 used in the production of head protective shells. It has also been proven that thermal loads contribute to significant degradation in strength and rigidity of tested materials, which affects adversely protective properties of the helmet.
\end{abstract}

\section{Introduction}

During rescue actions firefighters are exposed to elements that pose a hazard to health and life, including mechanical and thermal loads $[1,2]$. Personal protective equipment protect the firefighter from direct impact of such hazardous agents. Basic elements of personal protective equipment comprise: fire helmet, special clothing and gloves, balaclava, boots, respiratory apparatus including mask [3].

One of the most serious hazards to which a firefighter is exposed is mechanical injury to the head. Depending on the nature of the incident such injury may be caused by dynamic and static loads. In certain incidents, such as for example internal fires, mechanical loads

\footnotetext{
*Corresponding author: awalczak@sgsp.edu.pl
} 
are found to occur along with thermal loads. This leads to a cumulation of hazardous factors.

The helmet protects the firefighter's head from mechanical damage and other adverse elements, such as thermal load, flames, sparks, chemical and biological factors and electrical current. In Poland in accordance with provisions of the valid standard PN-EN 443 only type B helmets are allowed for use in firefighting units [4]. They are meant to protect the head and nape of the firefighter's neck, and shield a larger head area than type A helmets. Head protection consists of numerous elements, the main ones of which are: shell, visor, shock absorbing liner and suspension.

The shell is the external element of firefighter's helmet most exposed to external factors. The protective function of the shell is of particular importance, because it absorbs a considerable amount of energy coming from mechanical impact and shields from other hazards that occur during rescue actions [5]. The helmet shell material should guarantee a significant mechanical and thermal resistance. In currently used fire helmets the shells are usually made in the injection moulding technology using polymer composites, thermoplastics reinforced by cut fibres [6]. Formerly shells used to be made of structural composites - laminates of plastics reinforced by mats of glass fibres or kevlar type. They had different mechanical properties [7].

Thermal loads to which a firefighter is exposed during a fire impair the mechanical properties of the helmet shell materials. This is directly transposed on protective properties of the entire helmet. The impact of a thermal flux may cause the damage of chains of particles (units) of the composite material and may lead to decohesion of the polymer phase and reinforcing fibres. This type of damage causes the transfer of loads, degradation of strength and rigidity.

The advancement of technology enables the deployment of new technical solutions, enhancement of safety and comfort of the firefighters' work. Consequently it is important to study properties of new materials in different usage conditions to verify options of their possible use.

The objective of this study is to analyse changes on mechanical properties of polymer composites in conditions of thermal load, and consequently initial verification of possibilities of deploying new polymer composites for the production of fire helmet shells based on conducted compression testing.

\section{Materials and methods}

The reference material used in testing was the Ultramid composite, which is currently applied for production of Calisia Vulcan firefighter helmet shells by Kaliskie Zakłady Przemysłu Terenowego Kalisz. In addition three different materials were selected that contained reinforced by glass fibres bearing the trade name of: Tarnamid T-27, Tarnamid A3, and Tarnamid PPA. Those composites are manufactured in the Tarnów production plant, belonging to Grupa Azoty S.A. Basic information concerning the tested materials has been provided in table 1 .

Samples were prepared in the Polymer Processing Department of the Częstochowa University of Technology. They had been made in the mould injection technology on the KM65/160/C4 KraussMaffei device. The samples were rectangular-shaped with dimensions of $4 \times 10 \times 25 \mathrm{~mm}^{3}$ (fig. 1). 
Table 1. Properties of tested materials according to producers' data.

\begin{tabular}{|c|c|c|c|c|}
\hline & $\begin{array}{c}\text { Ultramid } \\
\text { PA66 GF25 }\end{array}$ & $\begin{array}{l}\text { Tarnamid T- } \\
27 \text { GF25 }\end{array}$ & $\begin{array}{l}\text { Tarnamid } \\
\text { A3 GF25 }\end{array}$ & $\begin{array}{r}\text { Tarnamid } \\
\text { PPA GF35 }\end{array}$ \\
\hline $\begin{array}{c}\text { Contents of glass fibres by } \\
\text { weight [\%] }\end{array}$ & 25 & 25 & 25 & 35 \\
\hline Melting point $\left[{ }^{0} \mathrm{C}\right]$ & 260 & 221 & - & $330-345$ \\
\hline Density $\left[\mathrm{g} / \mathrm{cm}^{3}\right]$ & 1.32 & 1.20 & - & 1.48 \\
\hline $\begin{array}{l}\text { Moisture absorption degree } \\
\text { (at temp. } 23^{\circ} \mathrm{C} \text { and relative } \\
\text { humidity of } 50 \% \text { ) [\%] }\end{array}$ & $1-1.4$ & 0.2 & 0.2 & 0.4 \\
\hline $\begin{array}{c}\text { Bending temperature at load of } \\
1.8 \mathrm{MPa}\left[{ }^{\circ} \mathrm{C}\right]\end{array}$ & 240 & 210 & - & 290 \\
\hline $\begin{array}{l}\text { Modulus of elasticity of dry } \\
\text { material [MPa] }\end{array}$ & 6500 & 5500 & - & 12500 \\
\hline
\end{tabular}

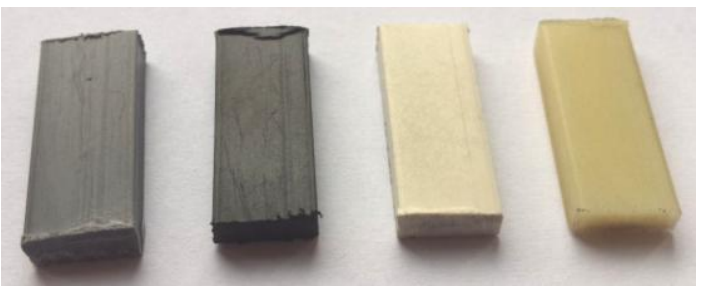

Fig. 1. Rectangular samples of polymer composites for compression testing (from the left: Tarnamid T-27 GF25, Ultramid PA66 GF25, Tarnamid PPA GF35, Tarnamid A3 GF25).

Strength tests were performed on the LabTest 6.100SP1-2-2300 universal testing system. Tests were conducted at different levels of thermal exposure according to data contained in table 2. Time and temperature of exposure were determined on the basis of Sawicki's work [8]. Testing at temperatures of $100^{\circ} \mathrm{C}, 140^{\circ} \mathrm{C}, 170^{\circ} \mathrm{C}$ took place after setting of the thermostat and heating of the chamber interior to the designed temperatures. Temperature was measured using a thermocouple provided close to the sample. Once the sample has been set up on the support, prior to execution of mechanical load there was a waiting time of $25 \mathrm{~min}$ for $100^{\circ} \mathrm{C}, 10 \mathrm{~min}$ for $140^{\circ} \mathrm{C}, 1 \mathrm{~min}$ for $170^{\circ} \mathrm{C}$, which was to simulate the environment of fire conditions. For each exposure level five tests were performed.

Table 2. Exposure times of samples in specific temperatures during testing.

\begin{tabular}{|c|c|}
\hline Time [min] & Temperature $\left[{ }^{\circ} \mathbf{C}\right]$ \\
\hline- & $20^{\circ} \mathrm{C}$ \\
\hline 25 & $100^{\circ} \mathrm{C}$ \\
\hline 10 & $140^{\circ} \mathrm{C}$ \\
\hline 1 & $170^{\circ} \mathrm{C}$ \\
\hline
\end{tabular}

\section{Results and analysis of test results}

Results of the compressive tests depending on the level of thermal exposure have been presented in tables 3-5. Table 3 presents descriptive statistics of values of compressive strength, table 4 - descriptive statistics of the Young's modulus, table 5 - average values of deformations at compressive strength. 
Table 3. Descriptive statistics of values of compressive strength.

\begin{tabular}{|c|c|c|c|c|c|c|c|}
\hline Temperature & Time & $\mathbf{N}$ & Mean & $\begin{array}{c}\text { Minimum } \\
\text { value }\end{array}$ & $\begin{array}{c}\text { Maximum } \\
\text { value }\end{array}$ & $\begin{array}{l}\text { Standard } \\
\text { deviation }\end{array}$ & $\begin{array}{l}\text { Variability } \\
\text { coefficient }\end{array}$ \\
\hline$\left[{ }^{\circ} \mathbf{C}\right]$ & {$[\mathrm{min}]$} & & \multicolumn{4}{|c|}{$[\mathrm{MPa}]$} & {$[\%]$} \\
\hline \multicolumn{8}{|c|}{ Ultramid PA66 GF25 } \\
\hline 20 & - & 5 & 83.37 & 79.5 & 87.14 & 2.75 & 3.3 \\
\hline 100 & 25 & 5 & 45.92 & 37.46 & 53.27 & 5.75 & 12.5 \\
\hline 140 & 10 & 5 & 32.87 & 28.2 & 35.94 & 3.57 & 10.85 \\
\hline 170 & 1 & 5 & 29.08 & 26.35 & 31.84 & 2.41 & 8.29 \\
\hline \multicolumn{8}{|c|}{ Tarnamid T-27 GF25 } \\
\hline 20 & - & 5 & 145.5 & 122 & 155.5 & 13.89 & 9.55 \\
\hline 100 & 25 & 5 & 67.07 & 56.97 & 78.68 & 9.1 & 13.57 \\
\hline 140 & 10 & 5 & 54.36 & 51.18 & 56.48 & 2.39 & 4.39 \\
\hline 170 & 1 & 5 & 42.03 & 37.06 & 46.83 & 3.9 & 9.28 \\
\hline \multicolumn{8}{|c|}{ Tarnamid A3 GF25 } \\
\hline 20 & - & 5 & 140.7 & 109.2 & 178 & 25.4 & 18.05 \\
\hline 100 & 25 & 5 & 79.52 & 53.8 & 105.3 & 18.38 & 23.11 \\
\hline 140 & 10 & 5 & 75.37 & 68.71 & 81.88 & 5.29 & 7.02 \\
\hline 170 & 1 & 5 & 57.07 & 48.53 & 63.43 & 5.85 & 10.25 \\
\hline \multicolumn{8}{|c|}{ Tarnamid PPA GF35 } \\
\hline 20 & - & 5 & 158.7 & 147.4 & 181.1 & 13.15 & 8.28 \\
\hline 100 & 25 & 5 & 119.2 & 104.4 & 127.9 & 10.2 & 8.56 \\
\hline 140 & 10 & 5 & 104.5 & 85.93 & 121.1 & 15.11 & 14.46 \\
\hline 170 & 1 & 5 & 68.47 & 59.28 & 78.44 & 8.54 & 12.47 \\
\hline
\end{tabular}

Materials produced by Grupa Azoty S.A. offer a much higher compressive strength (by over 65\%) than the Ultramid PA 66 GF25 material. From among the Tarnamid materials, the highest compressive strength was recorded for Tarnamid PPA GF35.

The strength of all the tested materials has undergone a significant decrease at elevated temperatures. The mean value of the strength offered by Ultramid PA66 GF25, Tarnamid T-27 GF25 and A3 GF25 at the temperature of $100^{\circ} \mathrm{C}$ is from 43 to $54 \%$ lower than at the temperature of $20^{\circ} \mathrm{C}$. The smallest change in strength was recorded for Tarnamid PPA GF35. The strength of that material at the temperature of $100^{\circ} \mathrm{C}$ is by $24 \%$ lower than at the temperature of $20^{\circ} \mathrm{C}$, and at $140^{\circ} \mathrm{C}$ - by $34 \%$. On the other hand, its strength at the temperature of $170^{\circ} \mathrm{C}$ was $57 \%$ lower than at the temperature of $20^{\circ} \mathrm{C}$. The biggest sensibility to thermal loads was recorded for the Tarnamid T-27 GF25 composite. Its strength at the temperature of $170^{\circ} \mathrm{C}$ is by $71 \%$ lower than at the temperature of $20^{\circ} \mathrm{C}$.

Table 4. Descriptive statistics of the Young module values obtained in compressive tests.

\begin{tabular}{|c|c|c|c|c|c|c|c|}
\hline Temperature & Time & $\mathbf{N}$ & Mean & $\begin{array}{c}\text { Minimum } \\
\text { value }\end{array}$ & $\begin{array}{c}\text { Maximum } \\
\text { value }\end{array}$ & $\begin{array}{l}\text { Standard } \\
\text { deviation }\end{array}$ & $\begin{array}{l}\text { Variability } \\
\text { coefficient }\end{array}$ \\
\hline$\left[{ }^{\circ} \mathbf{C}\right]$ & {$[\mathrm{min}]$} & & \multicolumn{4}{|c|}{ [MPa] } & {$[\%]$} \\
\hline \multicolumn{8}{|c|}{ Ultramid PA66 GF25 } \\
\hline 20 & - & 5 & 2057.54 & 1461.76 & 2704.56 & 446.47 & 21.7 \\
\hline 100 & 25 & 5 & 1331.00 & 1207.00 & 1599.00 & 155.2 & 11.66 \\
\hline 140 & 10 & 5 & 883.37 & 657.82 & 1070.57 & 179.79 & 20.35 \\
\hline 170 & 1 & 5 & 898.45 & 797.53 & 1175.64 & 160.22 & 17.83 \\
\hline \multicolumn{8}{|c|}{ Tarnamid T-27 GF25 } \\
\hline 20 & - & 5 & 4549.03 & 2081.85 & 5938.88 & 1467.53 & 32.26 \\
\hline 100 & 25 & 5 & 2371.73 & 1905.31 & 2609.7 & 294.86 & 12.43 \\
\hline 140 & 10 & 5 & 2004.92 & 1608.61 & 2160.48 & 265.29 & 13.23 \\
\hline 170 & 1 & 5 & 1774.83 & 1268.52 & 2242.02 & 420.09 & 23.67 \\
\hline
\end{tabular}




\begin{tabular}{|c|c|c|c|c|c|c|c|}
\hline Temperature & Time & $\mathbf{N}$ & Mean & $\begin{array}{l}\text { Minimum } \\
\text { value }\end{array}$ & $\begin{array}{c}\text { Maximum } \\
\text { value }\end{array}$ & $\begin{array}{l}\text { Standard } \\
\text { deviation }\end{array}$ & $\begin{array}{l}\text { Variability } \\
\text { coefficient }\end{array}$ \\
\hline$\left[{ }^{\circ} \mathrm{C}\right]$ & [min] & & \multicolumn{4}{|c|}{$[\mathrm{MPa}]$} & {$[\%]$} \\
\hline \multicolumn{8}{|c|}{ Tarnamid A3 GF25 } \\
\hline 20 & - & 5 & 4975.93 & 4422.18 & 5501.11 & 452.42 & 9.09 \\
\hline 100 & 25 & 5 & 2915.79 & 1957.81 & 3631.82 & 685.37 & 23.51 \\
\hline 140 & 10 & 5 & 3039.92 & 2384.06 & 3374.65 & 384.48 & 12.65 \\
\hline 170 & 1 & 5 & 2028.13 & 1131.03 & 2853.09 & 717.19 & 35.36 \\
\hline \multicolumn{8}{|c|}{ Tarnamid PPA GF35 } \\
\hline 20 & - & 5 & 5432.27 & 5178.26 & 5781.34 & 231.76 & 4.27 \\
\hline 100 & 25 & 5 & 4566.55 & 3795.54 & 5111.81 & 565.27 & 12.38 \\
\hline 140 & 10 & 5 & 3719.27 & 2756.23 & 4227.96 & 682.08 & 18.34 \\
\hline 170 & 1 & 5 & 2333.47 & 2144.02 & 2745.37 & 242.49 & 10.39 \\
\hline
\end{tabular}

Materials produced by Grupa Azoty S.A. have much higher values of the Young's modulus specified in the compression testing than Ultramid PA 66 GF25. The highest Young's modulus was recorded for the composite Tarnamid PPA GF35. Tarnamid T-27 GF25 and A3 GF25 despite similar strength and comparable contents of the reinforcing phase, are characterised by different rigidity.

At elevated temperatures the value of the Young's modulus determined in the compression testing of selected materials was found to decrease considerably. At the temperature of $100^{\circ} \mathrm{C}$ the value of the Young's modulus of material Ultramid PA66 GF25, Tarnamid T-27 GF25 and A3 GF25 was from 35\% to 48\% lower than at the temperature of $20^{\circ} \mathrm{C}$. The smallest rigidity change at $100^{\circ} \mathrm{C}$ was recorded for the composite Tarnamid PPA GF35 (decrease by $16 \%$ ). For this composite at the temperature of $140^{\circ} \mathrm{C}$ a decrease was recorded in the value of the Young's modulus by $32 \%$, at the temperature of $170^{\circ} \mathrm{C}-57 \%$. Biggest changes in rigidity under the impact of thermal loads were recorded for Tarnamid T-27 GF25.

Table 5. Mean deformation values obtained in compression test.

\begin{tabular}{|c|c|c|c|c|}
\hline \multirow[t]{2}{*}{ Material } & Temperature & Time & $\begin{array}{l}\text { Relative deformation } \\
\text { at compressive } \\
\text { strength of }\end{array}$ & $\begin{array}{l}\text { Absolute deformation } \\
\text { at compressive } \\
\text { strength of }\end{array}$ \\
\hline & {$\left[{ }^{\circ} \mathrm{C}\right]$} & [min] & {$[\%]$} & {$[\mathrm{mm}]$} \\
\hline \multirow{4}{*}{$\begin{array}{l}\text { Ultramid } \\
\text { PA66 GF25 }\end{array}$} & 20 & - & 4.44 & 1.04 \\
\hline & 100 & 25 & 5.56 & 1.24 \\
\hline & 140 & 10 & 5.27 & 1.28 \\
\hline & 170 & 1 & 4.87 & 1.13 \\
\hline \multirow{4}{*}{$\begin{array}{l}\text { Tarnamid } \\
\text { T-27 GF25 }\end{array}$} & 20 & - & 3.55 & 0.84 \\
\hline & 100 & 25 & 4.63 & 1.06 \\
\hline & 140 & 10 & 4.35 & 1.02 \\
\hline & 170 & 1 & 3.81 & 0.93 \\
\hline \multirow{4}{*}{$\begin{array}{l}\text { Tarnamid } \\
\text { A3 GF25 }\end{array}$} & 20 & - & 3.6 & 0.85 \\
\hline & 100 & 25 & 4.29 & 0.97 \\
\hline & 140 & 10 & 4.16 & 0.99 \\
\hline & 170 & 1 & 3.98 & 0.96 \\
\hline \multirow{4}{*}{$\begin{array}{l}\text { Tarnamid } \\
\text { PPA GF35 }\end{array}$} & 20 & - & 3.49 & 0.84 \\
\hline & 100 & 25 & 3.5 & 0.83 \\
\hline & 140 & 10 & 3.77 & 0.92 \\
\hline & 170 & 1 & 4.53 & 1.1 \\
\hline
\end{tabular}


Deformation at compressive strength of material Ultramid PA66 GF25 was found to be higher than that of materials manufactured by Grupa Azoty S.A. from 19 to $21 \%$. On the other hand, deformations of the Tarnamid materials are similar.

In the majority of cases deformations at compressive strength of tested materials are higher at elevated temperatures than at $20^{\circ} \mathrm{C}$. The change in values of deformations for Ultramid PA66 GF25, Tarnamid T-27 and A3 is of a different nature than for composite Tarnamid PPA GF35. As regards materials Ultramid PA66 GF25, Tarnamid T-27 and A3 the highest deformation values were recorded at $100^{\circ} \mathrm{C}$. As temperature grows, deformations tend to become reduced as compared to deformations obtained at the temperature of $100^{\circ} \mathrm{C}$. As regards Tarnamid PPA GF35, at the temperature of $100^{\circ} \mathrm{C}$ no significant deformations have been recorded. With an increase in temperature, deformations grow in relation to those recorded at the temperature of $100^{\circ} \mathrm{C}$.

\section{Conclusions}

On the basis of the results and analysis presented in the paper the following conclusions were made:

- The Tarnamid composites are characterised by higher compressive strength, rigidity (determined on the basis of the value of the Young's modulus) and smaller deformation at compressive strength than Ultramid PA66 GF25 that is used for production of fire helmet shells.

- Materials Tarnamid T-27 GF25 and Tarnamid A3 GF25 are characterised by different rigidity despite the same contents of the reinforcing phase and similar strength.

- Thermal loads contribute to considerable degradation of strength and rigidity of materials used to produce shells of firefighters' helmets which affects adversely its protective properties.

- Degradation of material properties of Tarnamid under the impact of thermal load is significant.

- Changes to properties of the Tarnamid PPA GF35 composite under the impact of thermal loads was of a different nature than in the vase of other tested materials.

- It is recommended that further tests be conducted of properties of the Tarnamid materials to verify behaviour of materials in conditions of different loads.

\section{References}

1. A. Gnatowski, Polimery 56, 2 (2011)

2. D.L. Smith, P.C. Fehling, E.M. Hultquist, W.K. Lefferts, D.A. Barr, T.W. Storer, CH. B. Cooper, Ergonomics 55, 1243 (2012)

3. C. Goodson, L. Murnane, Essentials of Fire Fighting, FPP Oklahoma State University (2008)

4. PN-EN 443:2008

5. A. Walczak, D. Pieniak, I. Naworol, W. Wąsik, P. Chudy, M. Sutuła, BiTP 2, 64 (2018)

6. D. Pieniak, R. Kamocka-Bronisz, A. Walczak, Logistyka 5, 1260 (2014)

7. S. Płaska, P. Stączek, M. Bogucki, A. Krzyżak, Czasopismo Techniczne. Mechanika 103, 387 (2006)

8. T. Sawicki, Bezpieczeństwo Pracy 7-8, 35 (2004) 